2nd International Conference Global Ethics -Key of Sustainability (GEKoS) | May 14, 2021 | Bucharest, Romania

\title{
The Impact of Working from Home During Pandemic Times on Employees Motivation in Romanian Insurance Companies
}

\author{
Bogdan ŞTEFĂNESCU
}

https://doi.org/10.18662/lumproc/gekos2021/11

How to cite: Ştefănescu, B. (2021). The Impact of Working from Home During Pandemic Times on Employees Motivation in Romanian Insurance Companies. In A. Grigorescu \& V. Radu (vol. ed.), Lumen Proceedings: Vol. 15. 2nd International Conference Global Ethics - Key of Sustainability (GEKoS) (pp. 125133). Iasi, Romania: LUMEN Publishing House. https://doi.org/10.18662/lumproc/gekos2021/11 


\title{
The Impact of Working from Home During Pandemic Times on Employees Motivation in Romanian Insurance Companies
}

\author{
Bogdan ŞTEFĂNESCU ${ }^{1}$
}

\begin{abstract}
This article represents an analysis of the impact on employees of insurance companies in Romania, of the changes that occurred following the crisis generated by the Coronavirus pandemic. With the implementation of traffic restrictions in the spring of 2020 and the introduction of quarantine in Romania, companies were forced to resort to alternative means of conducting and continuing the activity in safe conditions for employees. The main change was the implementation of work at home, doubled by a strong progress of digitalization in the field.

The orientation of companies towards the customer, the desire to offer the most complete services and the need to work as much as possible in the online environment, accelerated the digital transformation processes, offering a new perspective to both customers and employees who were able to experience a large number migrating to work from home.

This article pays more attention to the analysis of the direct relationship between staff motivation in the case of work at home and the results obtained, with the final result - the sustainability of the organization's activity.
\end{abstract}

Keywords: sustainability, motivation, digitalization, telework.

\footnotetext{
${ }^{1}$ Valahia University of Târgoviste, Targoviste, Romania, bogdanstefanescu@yahoo.com
} 


\section{Introduction}

Organizational studies in the 21st century are strongly oriented towards the analysis of the organizational climate, this being a defining element in motivating employees. Most of the authors (Kopelman, Brief, Guzzo, Petterson, Schneider, Ehrhart, Macey, Glick) agreed and concluded that we are talking about a complex and multidimensional term that must be clearly addressed in specialized analyzes (Morgan, 2020).

\section{Problem Statement}

The organizational climate derives from the employees' perception of the experiences they had at their working place, which is why we consider the approach of this topic in this paper to be fully justified (De Leeuw et al., 2014). The special epidemiological context that emerged in 2020 as a result of the Sars Cov2 pandemic has led to an unprecedented crisis situation in the last 100 years (since the Spanish flu of 1918), so that all organizations worldwide have had to innovate, to discover and implement new business sustainability strategies (Dubey \& Tripathi, 2020; Purwanto et al., 2020). We can say with certainty that in Romania there was a real revolution / evolution in the field, generated by the insignificant percentage (less than $1 \%$ ) of employees who worked both in the office and at home before the pandemic. Thus, in a few months, Romanian entities have developed the concept of working from home at a level of performance similar to office work. Insurance companies in our country, through the specifics of their activity, have toward rallied to the new order of things and have quickly taken enormous steps towards digitalization, transforming the organizational climate to a structure that is more digitalized and autonomous.

The new society is build based on knowledge and innovation and the globalization process created a very competitive environment for all companies (Grigorescu et al., 2020).

Although working from home is both a convenient and implementable option as a strategy to continue working in good conditions following the COVID-19 pandemic, in Romania, the percentage of employees working from home is below $20 \%$, being the lowest among the states of the European Union as a share of the conversion to telework in the aforementioned context (Zhan et al., 2020).

The success of organizational change depends largely on the quality of the chosen solutions and the efficiency of their implementation, which can generate consequences such as: effective implementation, innovation 
and increasing organizational performance (Teillet et al., 1997; Stegăroiu et al., 2020).

\section{Research Questions/Aims of the research}

The purpose of this research is to demonstrate that there is a direct relationship between new age benefits such as work from home and employees motivation whitch translate to organizational performance.

The organizational culture is directly influenced by the people's capacity to adapt to a fast changing environment, through a continous process of learning (Harries-Jones, 2008, p. 12.).

In order to be motivated, the employee must propose to know clearly what he has to do, to be provided with work procedures and to be familiar with the knowledge about the activity he carries out (Shinn, 1994, p. 307).

Organizational culture is the modern process of development (O'Connor, 2001). O'Connor, M. P. (2001). O'Connor, M. P. (2001).

The devastation wrought by the virus pandemic, adds one more bit of urgency to the calls for reform (Freeman, 2020).

\section{Research Methods}

In order to achieve the objective of analyzing the direct relationship between employees motivation in the case of work at home and the results obtained, resulting in the sustainability of the organization, we used as a research method quantitative analysis, based on a questionnaire, which was applied among employees of representative insurance companies in Romania.

\section{Findings}

This chapter presents the results obtained from the application of the questionnaire.

To the question: "To what extent do you consider that the responsibilities specific to your job can be fulfilled by working from home / telework?" $71.4 \%$ of respondents according to Chart 1 . appreciated to a large and very large extent, while $21.3 \%$ responded to a small and very small extent. Thus, for those who consider that they can only fulfill their tasks working from home only partially, the employer must ensure that in special 
crisis conditions they have all the logistical support starting from ensuring an internet connection and equipping with high-performance devices until to provide moral support by maintaining contact with the team through phone, email and dedicated applications.

Chart 1 . To what extent do you consider that the responsibilities specific

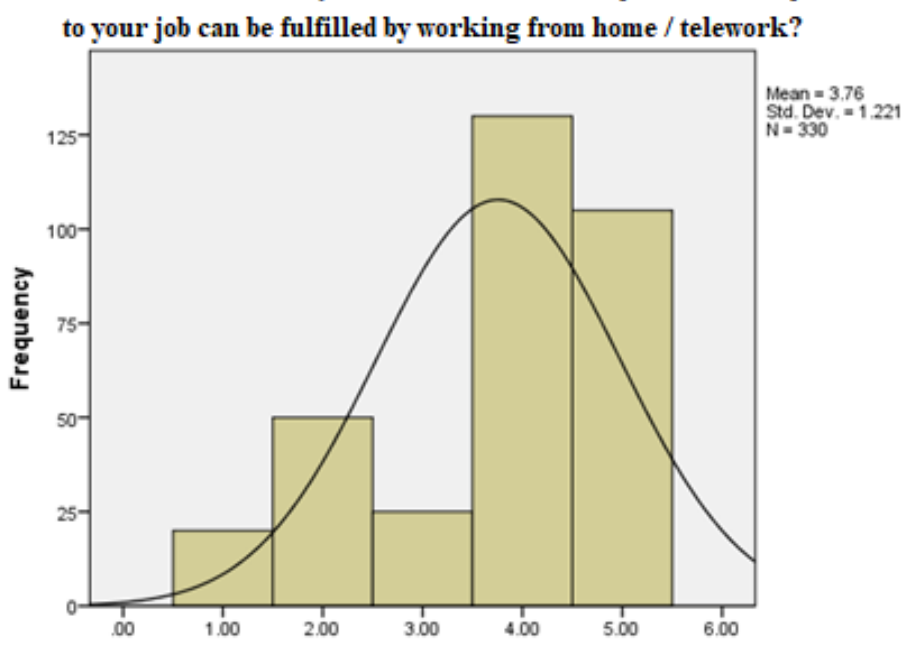

Source: by the author

Answers to the question: To what extent do you consider it important to establish a daily schedule / routine when working from home? " shows that $90.9 \%$ of the respondents according to Chart 2 . greatly and very much appreciated this aspect. Thus, it is more productive to establish daily routines, work intervals and air breaks. It is also advisable to have a well-planned lunch break.

Chart 2. To what extent do you consider it important to establish a daily schedule / routine when working from home?

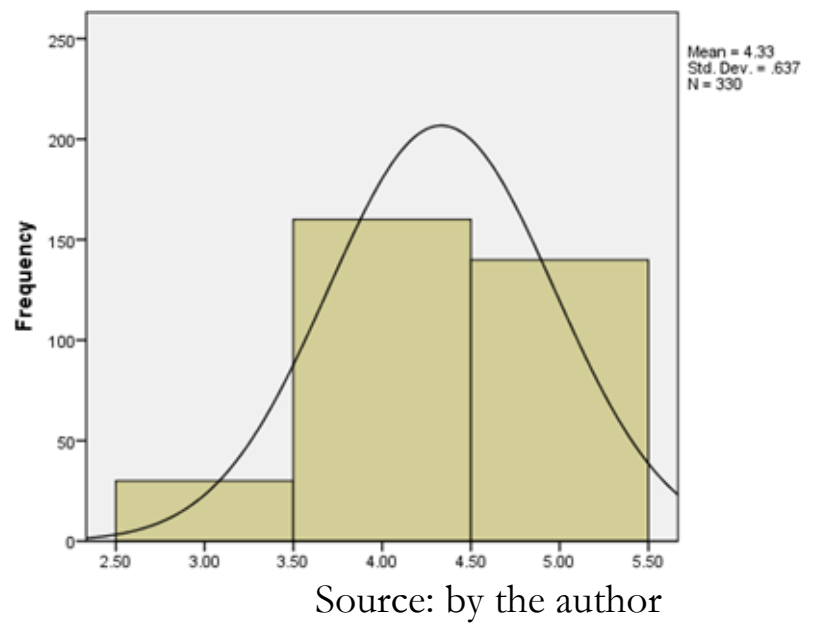


Opinion on the question: "To what extent do you consider that when you work from home it is important to separate the space where the professional activity takes place from the rest of the house?" shows that $83.4 \%$ of the respondents according to Chart 3. greatly and very much appreciated this aspect. To the extent possible, practice has shown that designating a workspace different from the rest of the home can help to achieve superior results.

Chart 3. To what extent do you consider that when you work from home it is important to separate the space where the professional activity takes place from the rest of the house?

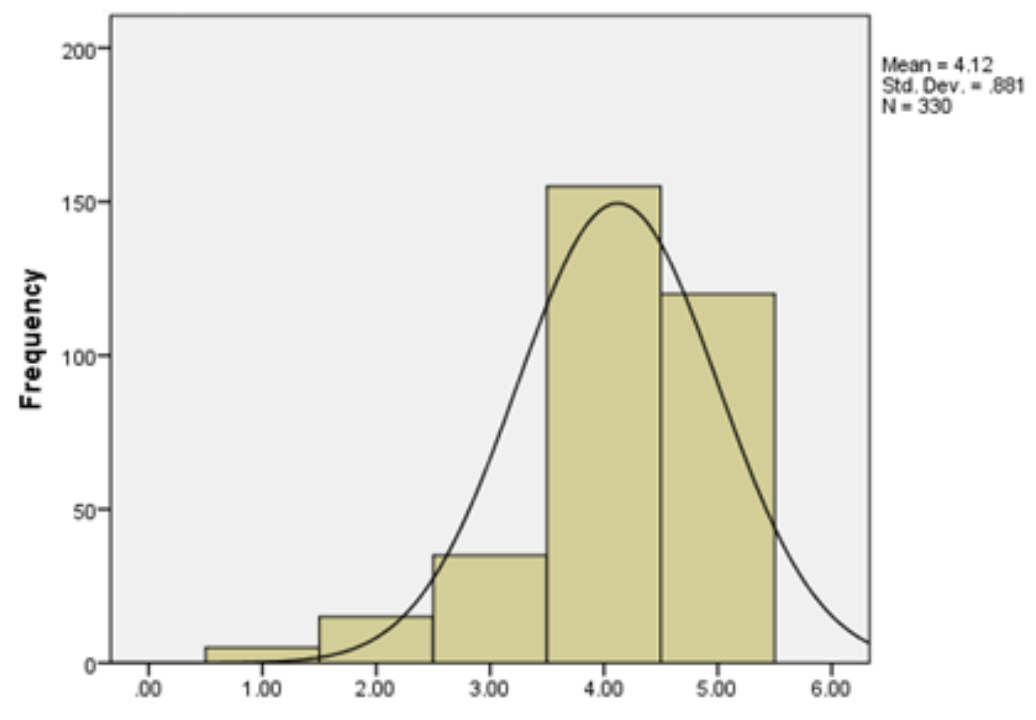

Source: by the author

Analyzing the answers to the question: "How often have you used video conferencing applications such as Skype, Zoom, Google Meets, Microsoft Teams, etc., to be related to:", $86.4 \%$ of respondents according to Chart 4. appreciate in large and very to a large extent use video conferencing applications to connect with the team for meetings or various information, $68.1 \%$ of respondents according to Chart 5 . appreciate to a large and very large extent that they use video conferencing applications to connect with their superior hierarchically, $51.5 \%$ of respondents according to Chart 6 . appreciate to a large and very large extent that they use videoconferencing applications to connect with colleagues in support departments, and 31.8\% of respondents according to Chart 7. appreciate and to a large extent use video conferencing applications to connect with customers for the purpose of presenting offers and products. 
Bogdan ŞTEFĂNESCU | Lumen Proceedings 15 | GEKoS 2021

Chart 4. How often have you used video conferencing applications such as Skype, Zoom, Google Meets, Microsoft Teams, etc.

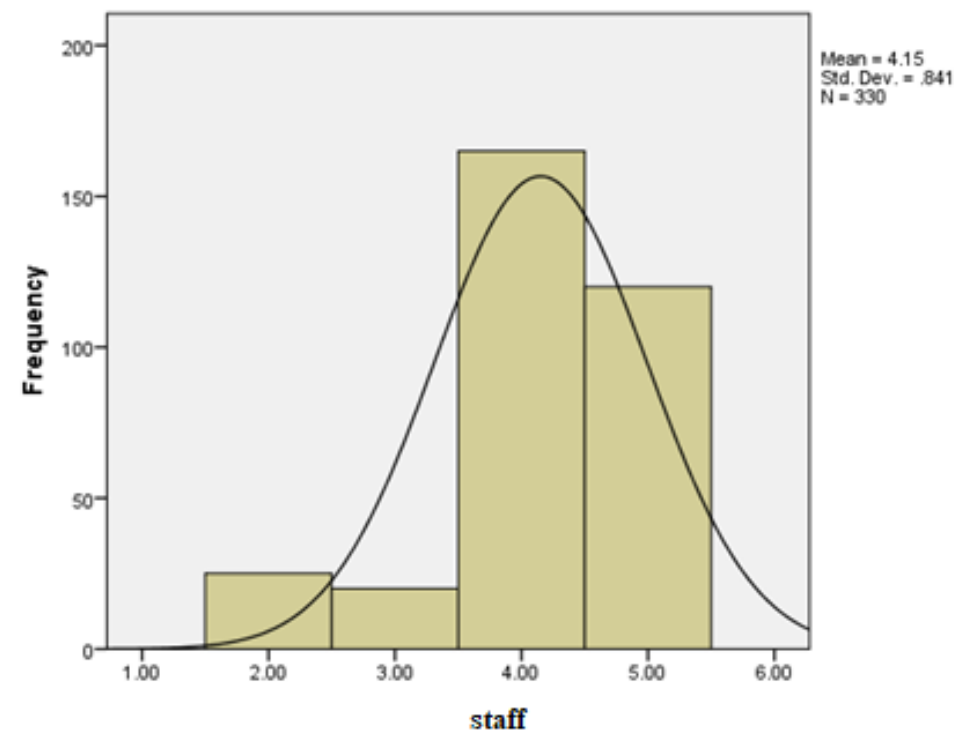

Source: by the author

Chart 5. How often have you used video conferencing applications such as Skype, Zoom, Google Meets, Microsoft Teams, etc.

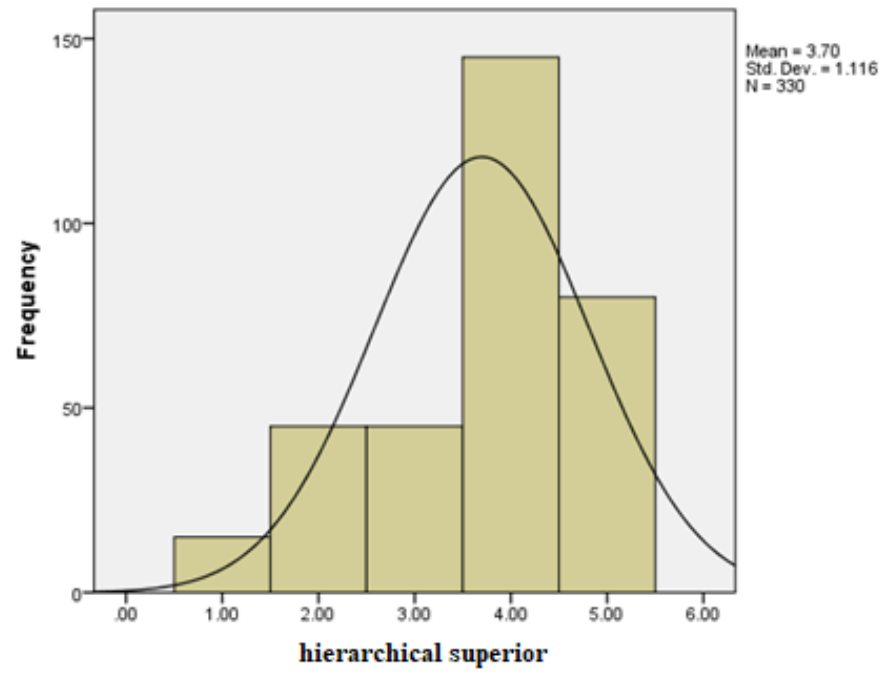

Source: by the author 
Chart 6. How often have you used video conferencing applications such as Skype, Zoom, Google Meets, Microsoft Teams, etc.

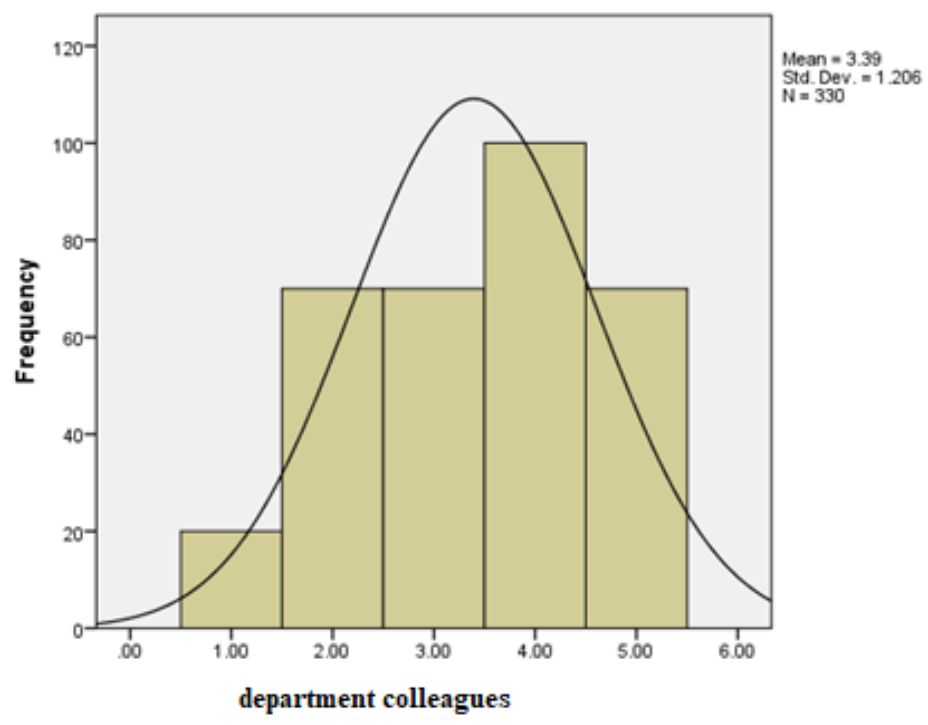

Source: by the author

Chart 7. How often have you used video conferencing applications such as Skype, Zoom, Google Meets, Microsoft Teams, etc.

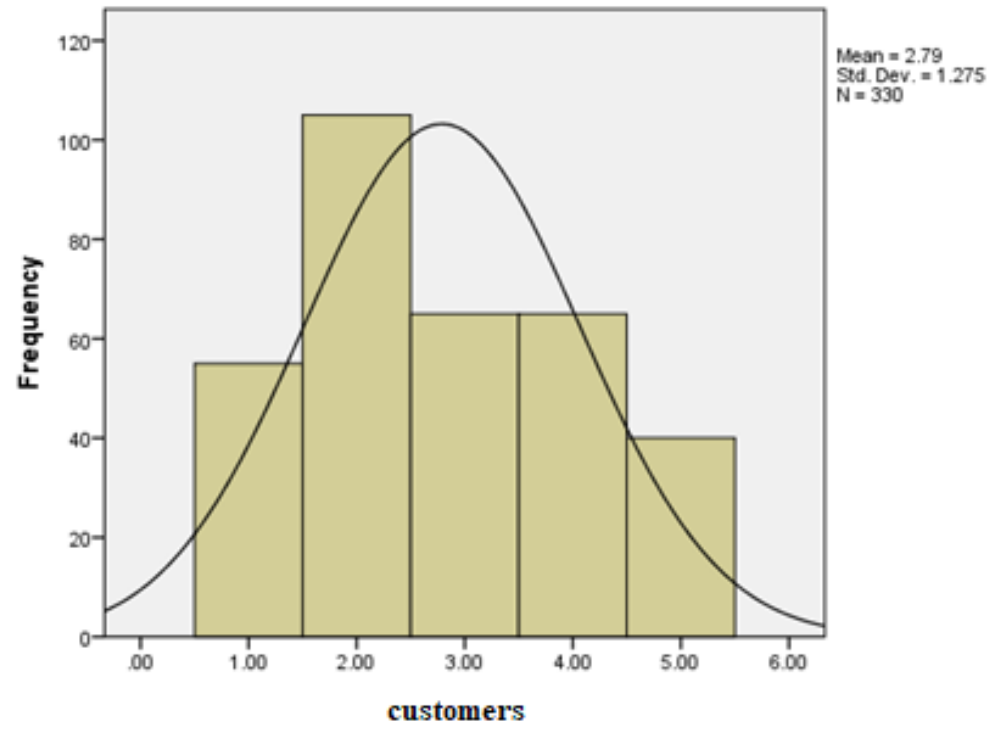

Source: by the author 
There is a concern of the management in the analyzed companies to maintain the cohesion of the team and the good development of the activity by organizing sales meetings, trainings and information on news through videoconferencing, managers to have a permanent connection with each subordinate employee, the operation of business flows. support and interdepartmental links within companies. The percentage of $31.8 \%$ of respondents who use video conferencing applications to a large and very large extent to keep in touch with customers is a good one for 2020, but we believe that it should increase to $100 \%$ (all employees in this field should they can be prepared to hold an online meeting with a potential customer, in which they can access the applications for bidding, screen sharing, sending offers by email, electronic signing of documents, etc.).

\section{Conclusions}

The questionnaire applied to the employees of the insurance companies in Romania shows a tendency of the management to lean towards the creation of favorable, stimulating working conditions, with the reduction of stress and the reward of work according to the obtained results. Working conditions, benefits in kind such as the company car, laptop and the telephone and internet subscription offered by the employer were also motivational factors that led to organizational performance.

\section{References}

De Leeuw, J., Vrieling, A., Shee, A., Atzberger, C., Hadgu, K. M., Biradar, C. M., Keah, H., \& Turvey, C. (2014). The potential and uptake of remote sensing in insurance: A review. Remote Sensing, 6(11), 10888-10912.

https://doi.org/10.3390/rs61110888

Dubey, A. D, \& Tripathi, S. (2020). Analysing the sentiments towards work-fromhome experience during covid-19 pandemic. Journal of Innovation Management, 8(1), 13-9. https://doi.org/10.24840/2183$\underline{0606 \quad 008.001 \_0003}$

Freeman, R. E. (2020). Business Ethics in the Time of Covid-19. In A. Grigorescu\& V. Radu(vol. ed.), Lumen Proceedings: Vol. 11. 1st International Conference Global Ethics -Key of Sustainability (GEKoS) (pp. 1-3). Iasi, Romania: LUMEN Publishing House.

https://doi.org/10.18662/lumproc/gekos2020/01. 
Grigorescu, A., Lincaru, C., \& Pîrciog, S. (2020). Ethic Leadership Trigger for

Talents. In A. Grigorescu \& V. Radu (vol. ed.), Lumen Proceedings: Vol. 11.

1st International Conference Global Ethics -Key of Sustainability (GEKoS) (pp. 32-

44). Iasi, Romania: LUMEN Publishing House.

https://doi.org/10.18662/lumproc/gekos2020/05

Harries-Jones, P. (2008). Cultural perspectives and sustainability. EOLSS Publishers Ltd.

Morgan, H. (2020). Best practices for implementing remote learning during a pandemic. The Clearing House: A Journal of Educational Strategies, Issues and Ideas, 93(3), 135-41. https://doi.org/10.1080/00098655.2020.1751480

O’Connor, M. P. (2001). Cultural Development Information And Knowledge, Principles Of Sustainable Development. Encyclopedia of Life Support Systems, 127-145. http://www.eolss.net/sample-chapters/c13/E1-46A-05-02.pdf

Purwanto, A., Asbari, M., Fahlevi, M., Mufid, A., Agistiawati, E., Cahyono, Y., \& Suryani, P. (2020). Impact of Work From Home (WFH) on Indonesian Teachers Performance During the Covid-19 Pandemic: An Exploratory Study. International Journal of Advanced Science and Technology, 29(5), 6235-44. https://www.researchgate.net/publication/341413246_Impact of Work From Home WFH on Indonesian Teachers Performance During the Covid-19 Pandemic An_Exploratory Study

Shinn, G. (1994). The miracle of motivation. The action guide to happiness and success. Tyndale House Publishers.

Stegăroiu, I., Radu, V., Simsek, H., \& Tăbîrcă, A. I. (2020). Impact of Leadership Team Values and Performance on Organizational Behavior. In I. Panagoret, \& G. Gorghiu (vol. ed.), Lumen Proceedings: Vol. 10. International Conference Globalization, Innovation and Development. Trends and Prospects (G.I.D.T.P.) (pp.241-251). Iasi, Romania: LUMEN Publishing House. https://doi.org/10.18662/lumproc/gidtp2018/27

Teillet, P. M., Horler, D. N., \& O'Neill, N. T. (1997). Calibration, validation, and quality assurance in remote sensing: A new paradigm. Canadian journal of remote sensing, 23(4), 401-14.

https://doi.org/10.1080/07038992.1997.10855225

Zhan, X., Popescu, D. M., \& Radu, V. (2020). Challenges for Romanian Entrepreneurs in Managing Remote Workers. In M. W. Staniewski, V. Vasile, \& A. Grigorescu (vol. ed.), Lumen Proceedings: Vol. 14. International Conference Innovative Business Management \& Global Entrepreneurship (IBMAGE 2020) (pp. 670-687). Iasi, Romania: LUMEN Publishing House. https://doi.org/10.18662/lumproc/ibmage2020/49 